\title{
Minat Belajar Peserta Didik pada Mata Pelajaran Ekonomi di Masa Pandemi COVID-19
}

\author{
${ }^{1}$ Christian Ade Pradana, ${ }^{2}$ Riza Yonisa Kurniawan \\ 1Mahasiswa Pendidikan Ekonomi, Universitas Negeri Surabaya \\ 2Dosen Pendidikan Ekonomi, Universitas Negeri Surabaya \\ E-mail: christianade01@gmail.com, rizakurniawan@unesa.ac.id
}

\begin{abstract}
Article Info
Article History

Received: 2021-03-12

Revised: 2021-04-20

Published: 2021-06-02

Keywords:

E-learning;

Learning;

Interest;

Economic.

\section{Abstract}

This pandemic has an impact not only in the health sector but also on various fields such as economics and education. In the field of education, this is very influential on students who are gaining knowledge. Several studies have shown that the implementation of online learning has experienced several obstacles. This study aims to analyze students' interest in learning in Economics during the COVID-19 pandemic. This research is a descriptive study with a qualitative approach. The technique of taking the subject in this study used a sampling technique, the sampling technique chosen by the researcher was purposive sampling. Based on the research obtained, it shows that the application of e-learning has an influence on students' interest in learning in economic subjects during the Covid-19 pandemic.
\end{abstract}

\begin{tabular}{l}
\hline Artikel Info \\
\hline Sejarah Artikel \\
Diterima: 2021-03-12 \\
Direvisi: 2021-04-20 \\
Dipublikasi: 2021-06-02
\end{tabular}

Kata kunci:

Pembelajaran;

E-learning;

Minat Belajar;

Ekonomi.

\begin{abstract}
Abstrak
Pandemi ini tidak hanya berdampak di bidang kesehatan tetapi juga berdampak di berbagai bidang seperti ekonomi dan pendidikan Pada bidang pendidikan hal ini sangat berpengaruh pada peserta didik yang sedang menimba ilmu. Beberapa penelitian menunjukkan bahwa pelaksanaan pembelajaran secara online mengalami beberapa permasalahan. Penelitian ini bertujuan untuk menganalisis bagaimana minat belajar peserta didik pada mata pelajaran Ekonomi di masa pandemi COVID-19, Penelitian ini merupakan penelitian deskriptif dengan pendekatan kualitatif. Teknik pengambilan subjek pada penelitian ini menggunakan teknik sampling, teknik sampling yang akan dipilih oleh peneliti adalah purposive sampling. Berdasarkan penelitian yang diperoleh menunjukkan bahwa penerapan pembelajaran e-learning membawa pengaruh terhadapat minat belajar peserta didik pada mata pelajaran ekonomi di masa pandemi covid-19.
\end{abstract}

\section{PENDAHULUAN}

Pada saat ini dunia sedang digemparkan dengan mewabahnya sebuah virus yang bernama Corona atau yang sering kita kenal dengan COVID-19. Virus ini pertama munculnya di Kota Wuhan, Tiongkok dan dengan cepat menyebar ke seluruh dunia. COVID-19 merupakan penyakit yang di akibatkan oleh virus yang bernama SARS-COV-2. Virus ini tidak hanya menyebabkan flu, namun juga menyebabkan penderitanya mengalami gangguan pernapasan sampai kematian. Virus ini menyebar melalui droplet pasien yang terinfeksi, seseorang akan terinfeksi jika kekebalan imun lemah. Ada beberapa cara pencegahan yang dapat dilakukan untuk memutus mata rantai penyebaran COVID-19 antara lain vaksin, deteksi dini dan isolasi, higiene, cuci tangan, dan disinfeksi, alat pelindung diri, mempersiapkan daya tahan tubuh (Susilo et al., 2020).

Pandemi COVID-19 adalah masa-masa yang sulit bagi seluruh dunia. Tak hanya memikirkan bagaimana cara terbebas dari wabah virus ini tetapi juga bagaimana harus tetap berjalannya setiap bidang- bidang pendukung dari sebuah Negara. Tak terkecuali di bidang pendidikan, pendidikan memberikan pengaruh dan kontribusi yang sangat besar bagi perkembangan diri seseorang. Mewabahnya virus ini membawa dampak yang cukup besar bagi kebutuhan akan pendidkan.

Kebutuhan akan pendidikan dinilai sangat krusial bagi generasi muda serta bangsa dan Negara. Hal ini dikarenakan pendidikan bertugas menyiapkan dan mematangkan Sumber Daya Manusia generasi muda bagi pembangunan bangsa dan Negara. Pemerintah harus berpikir bagaimana pendidikan harus tetap berjalan dengan baik di tengah masa yang mewajibkan semua orang membatasi diri untuk saling bertemu. Terlebih lagi sejak pertama kali pada awal bulan Maret diumumkannya penyebaran COVID-19 di Indonesia, kondisi pendidikan mengalami perubahan mekanisme dimana pemerintah meliburkan serentak kegiatan belajar mengajar secara langsung dan kemudian dialihkan menjadi Study From Home. Menteri Pendidikan dan Kebudayaan Republik Indonesia mengeluarkan Surat Edaran Nomor 4 
Tahun 2020 Tentang Pelaksanaan Kebijakan Pendidikan Dalam Masa Daruat Penyebaran COVID, pada surat tersebut menjelaskan bahwa kegiatan pembelajaran dijalankan di rumah melalui pembelajaran daring/jarak jauh.

Munculnya trobosan baru dengan adanya proses pembelajaran jarak jauh di bidang pendidikan ini merupakan solusi tepat yang diambil pemerintah guna menekan tingginya resiko penyebaran COVID19. Bencana pandemi ini sedang melanda seluruh dunia namun tak menyurutkan proses pembelajaran, pembelajaran harus tetap berlangsung di tengah pandemi yang sedang dirsakan. Kegiatan belajar mengajar dimulai dengan menggunakan pemanfaatan komputer serta jaringan internet dalam kegiatan pembelajaran, yang dikenal dengan istilah e-learning atau pembelajaran dalam jaringan (daring) (Setiawardhani, 2013). E-learning pada hakikatnya adalah proses pembelajaran dengan memanfaatkan media digital serta elektronik seperti multimedia. $E$ learning merupakan proses kegiatan belajar mengajar berbasis komputer baik internet maupun media elektronik sebagai instrumennya, keduanya tetap berfokus pada pembelajarannya, bukan pada media atau perangkat yang digunakan pada proses pembelajaran (Maya Rahmatia, Monawati, 2017).

Pembelajaran daring (e-learning) ini memberikan banyak sekali dampak, dampak dalam hal positif maupun dalam hal negatif. Dalam proses pembelajaran guru dituntut untuk menyampaikan sebuah materi dengan sekreatif mungkin, terutama di kalangan peserta didik. Pembelajaran seperti ini tidaklah mudah karena selain melibatkan guru dan peserta didik, orang tua juga memiliki peran yang cukup tinggi dalam mendukung keberhasilan proses pembelajaran. Pengadaan jaringan internet yang stabil dan lancer harus disipakan oleh orang tua. Jaringan internet yang lemah akan menyebabkan kendala dalam proses pembelajaran. Menurut hasil penelitian menunjukkan bahwa lingkungan belajar berpengaruh terhadap hasil belajar peserta didik (Sholihah, 2016).. Selain itu poses pembelajaran melalui e-learning ini juga membuat guru merasa cukup kesulian, disebabkan kurangnya minat peserta didik dalam mengikuti proses pembelajran.

Minat yang dimiliki oleh seseorang tidak begitu saja muncul secara lahir, melainkan melalui proses yang relatif cukup lama. Minat belajar ialah salah satu peran penting yang dimiliki oleh peserta didik dalam kegiatan belajar mengajar (Pratiwi, 2015). Faktor luar dari minat belajar adalah bagaimana cara yang diterapkan oleh guru dalam mengajar. Peran guru sangatlah penting guna menumbuhkan minat belajar peserta didik, salah sau caranya dengan membuat pembelajaran yang menyenangkan, dan memberikan motivasi yang membangun (Ninu Septiani, 2016).

Minat dapat diartikan sebagai adanya ketertarikan dan perasaan suka terhadap aktivitas maupun suatu hal, tanpa adanya paksaan. Dengan kata lain, minat adalah suatu rasa senang lebih besar dalam memberikan perhatian terhadap objek tertentu
(Anam, 2015). Minat belajar memiliki peran yang cukup signifikan dalam belajar. Indikator yang terdapat dalam minat belajar anatara lain adanya rasa tertarik dan senang dalam belajar, adanya kecenderungan, serta kenyamanan saat belajar.

Minat belajar tinggi yang dimiliki oleh peserta didik akan memberikan usaha penuh dalam kegiatan pembelajaran. Dengan minat yang tinggi pula peserta didik mampu belajar dengan baik, sehingga pesera didik akan lebih mudah untuk berpikir secara kritis, kreatif dan efektif yang akan menjadikan peserta didik dapat meraih prestasi dalam pembelajaran (Sirait, 2016).

Hal ini mendorong penulis untuk melakukan penelitian tentang "Analisis Pembelajaran E-learning Terhadap Minat Belajar Peserta Didik Pada Mata Pelajaran Ekonomi Di Masa Pandemi Covid-19". Dengan penelitian ini diharapkan dapat membantu pihak sekolah dalam mengetahui sejauh mana proses pembelajaran E-Learning peserta didik dan minat belajar Ekonomi peserta didik dalam menjalani pembelajaran E-Learning di tengah pandemi Covid-19.

\section{METODE PENELITIAN}

Penelitian ini merupakan penelitian deskriptif dengan pendekatan kualitatif. Penelitian deskriptif ialah penelitian yang memiliki tujuan untuk menyelidiki sebuah paparan dan gambaran secara sistematis, nyata, serta tepat mengenai fenomena antar hubungan (Wina, 2013). Penelitian kualitatif merupakan proses kegiatan penelitian yang bertujuan untuk memperoleh hasil ucapan atau tulisan, data deskriptif dan perilaku yang dapat diamati dari seseorang atau subjek itu sendiri (Ahmadi, 2014). Penelitian kaulitatif tidak digunakan untuk menguji hipotesis seehingga tidak ada kata signifikasi, Waktu dan Lokasi Penelitian yang diambil oleh peneliti dalam penelitian ini berada di SMA Labschool Unesa yang beralamat di Citraraya Unesa Rd, Lidah Wetan, Lakarsantri, Kota Surabaya. Adapun penelitian ini akan dilaksanakan pada bulan Februari 2021, Dengan Target/Subjek Penelitian adalah peserta didik kelas X IPA 1 SMA Labschool Unesa.

Teknik pengambilan subjek dalam penelitian ini menggunakan teknik sampling, teknik sampling yang dipilih oleh peneliti adalah purposive sampling. Purposive sampling ialah cara pengambilan sampel sumber data dengan mempertimbangan faktor khusus. Yang di maksud dari mempertimbangan faktor khusus ini adalah, narasumber tersebut dirasa paling mengerti tentang beberapa hal yang diharapkan oleh peneliti. Hal ini bertujan untuk membantu peneliti dalam menyelidiki objek/keadaan sosial yang sedang diteliti, Prosdur atau teknik pengumpulan data yang diterapkan dalam penelitian kualitatif ini merujuk pada keadaan yang sebenarnya dan teknik pengumpulan data dititikberatkan pada wawancara yang mendalam, observasi, serta dokumentasi (Nuri, 2017).

Teknik Analisis Data yang digunakan dalam penelitian ini merupakan teknik untuk mencari, 
menata, menemukan temuan baru yang terjadi di lapangan serta bahan lainya yang diperoleh dari hasil wawancara secara sistematis. Sehingga memudahkan untuk memhami serta hasil dari temuan tersebut dapat dijadikan sebagai informasi untuk peneliti lain (Partyaningsih, 2020), Langkah-langkah prosedur analisis menurut (Helaluddin \& Wijaya, 2019) diantaranya 1) Reduksi Data, 2) Display Data, 3) Kesimpulan

\section{HASIL DAN PEMBAHASAN}

\section{A. Hasil Penelitian}

1. Pembelajaran e-learning di SMA Labschool pada masa pendemi COVID-19

Pembelajaran e-learning dapat ditinjau dari beberapa indikator. Indikator tersebut meliputi pengetahuan tentang $e$ - learning, karakteristik $e$ learning, kelebihan $e$ - learning, dan kelemahan $e$ learning. Hasil paparan data yang didapat pada tiap indikator adalah sebagai berikut:

Hasil wawancara mengenai proses penerapan pembelajaran e-learning, narasumber menyatakan bahwa:

"Untuk pembelajaran lewat daring kak, seperti g-meet" (2/W/LA/15-03-2021)

"Selama pandemi sekolah memberikan pembelajaran berupa meteri yang di dapat via zoom/gmeet" (4/W/ANA/16-03-2021)

"Pembelajaran lewat zoom kak" (5/W/AKBG/15-03-2021)

Hal serupa juga disampaikan oleh narasumber dengan inisial SM selaku guru ekonomi kelas $\mathrm{X}$ SMA Labschool Unesa.

"Pada masa pendemi ini proses pembelajaran tetap berlangsung secara online melalui beberapa aplikasi yang menunjang pembelajaran selain itu sekolah juga bekerja sama dengan aplikasi pembelajaran yang bisa memudahkan peserta didik mengakses materi pembelajaran dengan mudah. Namun berbeda halnya dengan pembelajaran secara langsung, selama pandemi ini proses pembelajaran e-learning hanya berlangsung selama 1 jam" (1/W/SMS/26-02-2021)

Paparan data diatas menunjukkan bahwa pengetahuan tentang e-learning di SMA Labshool Unesa sebagian besar sudah cukup baik hal itu juga di tunjang dari kuisioner yang telah diisi oleh peserta didik di kelas X IPA 1 sebagai berikut:

Tabel 2. Selama pandemi covid-19 saya mampu menerapkan pembelajaran e-learning dengan baik

\begin{tabular}{ccc}
\hline $\begin{array}{c}\text { Alternatif } \\
\text { Jawaban }\end{array}$ & $\begin{array}{c}\text { Frekuensi } \\
\text { Informan }\end{array}$ & \% \\
\hline Ya & 21 & 75 \\
\hline Tidak & 7 & 25 \\
\hline Total & 28 & 100 \\
\hline
\end{tabular}

Tabel diatas menunjukan sebagian besar peserta didik mampu menerapkan pembelajaran $e$ learning karena sebanyak 21 dari 28 peserta didik mampu menerapkan pembelajaran e-learning dengan baik.

\section{a) Karakteristik pembelajaran E-learning}

Pada indikator karakteristik e-learning ditinjau dari interaktivitas, kemandirian, serta aksesibilitas, Kuisioner pada tabel berikut menunjukkan bahwa sebanyak 24 dari 28 peserta didik menjadi mandiri dalam belajar dengan adanya penerapan pembelajaran e-learning

Tabel 2. Penerapan pembelajaran e-learning menjadikan saya dapat belajar secara mandiri

\begin{tabular}{ccc}
\hline $\begin{array}{c}\text { Alternatif } \\
\text { Jawaban }\end{array}$ & $\begin{array}{c}\text { Frekuensi } \\
\text { Informan }\end{array}$ & \% \\
\hline Ya & 21 & 75 \\
\hline Tidak & 7 & 25 \\
\hline Total & 28 & 100 \\
\hline
\end{tabular}

Tabel diatas menunJukan sebagian besar peserta didik mampu menerapkan pembelajaran $e$ learning karena sebanyak 21 dari 28 peserta didik mampu menerapkan pembelajaran e-learning dengan baik.

\section{b) Karakteristik pembelajaran E-learning}

Pada indikator karakteristik e-learning ditinjau dari interaktivitas, kemandirian, serta aksesibilitas, Kuisioner pada tabel berikut menunjukkan bahwa sebanyak 24 dari 28 peserta didik menjadi mandiri dalam belajar dengan adanya penerapan pembelajaran e-learning

Tabel 3. Penerapan pembelajaran e-learning menjadikan saya dapat belajar secara mandiri

\begin{tabular}{ccc}
\hline $\begin{array}{c}\text { Alternatif } \\
\text { Jawaban }\end{array}$ & $\begin{array}{c}\text { Frekuensi } \\
\text { Informan }\end{array}$ & \% \\
\hline Ya & 24 & 85,7 \\
\hline Tidak & 4 & 14,3 \\
\hline Total & 28 & 100 \\
\hline
\end{tabular}

Tabel 4. Saya dapat menggunakan bahan ajar atau petunjuk belajar yang terstruktur dan terjadwal melalui pembelajaran e-learning

\begin{tabular}{ccc}
$\begin{array}{c}\text { Alternatif } \\
\text { Jawaban }\end{array}$ & $\begin{array}{c}\text { Frekuensi } \\
\text { Informan }\end{array}$ & $\mathbf{\%}$ \\
\hline Ya & 21 & 75 \\
\hline Tidak & 7 & 25 \\
\hline Total & 28 & 100 \\
\hline
\end{tabular}

Selain itu hasil kuisioner pada tabel 4.4 menyatakan bahwa 21 dari 28 peserta didik mampu menggunakan bahan ajar atau petunjuk belajar yang terstruktur dan terjadwal melalui pembelajaran e-learning dengan baik. Hal ini menunjukkan bahwa karakteristik pembelajaran $e$ learning yang di terapkan di SMA Labschool Unesa sudah berjalan dengan baik. 


\section{c) Manfaat pembelajaran E-learning}

Indikator manfaat e-learning ditinjau dari kemudahan berkomunikasi, kemudahan mereview pelajaran, dan kemudahan belajar, Dari hasil wawancara dengan narasumber mengatakan bahwa:

"Lebih praktis kak, nggak ribet soalnya kan online lewat hp/laptop dan komunikasinya gampang" (3/W/MRS/15-03-2021)

"Lebih berkembang kak, soalnya kan kalau dijelasin terus tiba-tiba ada kendala sinyal gitu kan ketinggalan jadi harus belajar lagi maetri yang sudah di berikan" (5/W/AKBG/15-032021)

"Tidak perluh pulang pergi ke sekolah, serta bisa belajar dan megerjakan tugas kapanpun saat dirumah" (4/W/ANA/16-03-2021)

Hal ini menunjukkan bahwa sebagian besar peserta didik merasakan manfaat dari pembelajaran e-learning. Selain itu, berdasarkan kuisioner pad tabel berikut.

Tabel 5. Melalui pembelajaran e-learning saya dapat berkomunikasi dengan guru dan temanteman yang lainnya dengan mudah tanpa dibatasi jarak, tempat dan waktu

\begin{tabular}{ccc}
\hline $\begin{array}{c}\text { Alternatif } \\
\text { Jawaban }\end{array}$ & $\begin{array}{c}\text { Frekuensi } \\
\text { Informan }\end{array}$ & $\mathbf{\%}$ \\
\hline Ya & 22 & 78,6 \\
\hline Tidak & 6 & 21,4 \\
\hline Total & 28 & 100 \\
\hline
\end{tabular}

Menunjukkan bahwa dengan penerapan pembelajaran e-learning sebagian besar peserta didik merasakan dapat berkomunikasi dengan guru dan teman-teman yang lainnya dengan mudah tanpa dibatasi jarak, tempat dan waktu, dengan demikian manfaat dari pembelajaran $e$ learning sudah dirasakan dengan baik di SMA Labschool, Hal tersebut juga didukung pernyataan dari Ibu SM selaku guru ekonomi kels X SMA Labschool, yang menyatakan bahwa:

"Dengan adanya pembelajaran e-learning peserta didik menjadi tanggap teknologi, selain itu guru juga dituntut menjadi lebih paham tentang teknologi. Untuk kelebihan lain yang dirasakan dari pihak sekolah adalah bisa memperbaiki infrastruktur sekolah" (1/W/SMS/26-02-2021).

\section{d) Kendala pembelajaran E-learning}

Pada indikator kendala kendala e-learning dapat ditinjau dari jaringan Internet, dan interaksi berkurang.
Tabel 6. Selama pandemi saya mengalami kesulitan akses jaringan dalam mengikuti pembelajaran e-learning

\begin{tabular}{ccc}
\hline $\begin{array}{c}\text { Alternatif } \\
\text { Jawaban }\end{array}$ & $\begin{array}{c}\text { Frekuensi } \\
\text { Informan }\end{array}$ & \% \\
\hline Ya & 14 & 50 \\
\hline Tidak & 14 & 50 \\
\hline Total & 28 & 100 \\
\hline
\end{tabular}

Dari kuisioner pada tabel 6 menunjukkan bahwa sebanyak 14 dari 28 peerta didik mengalami kesulitan akses jaringan dalam mengikuti pembelajaran e-learning. Pernyataan tersebut diungkap oleh narasumber dalam wawancara yang mengatakan bahwa:

"Kalau sinyal sama kuota tidak ada kendala, kalau materi itu beberapa tidak paham, materi yang diberikan hanya dasar-dasar" (2/W/LA/15-03-2021)

"Kendala saya cuma koneksi saja pak" (3/W/MRS/15-03-2021)

"Kendala yang saya hadapi biasannya gangguan sinyal pak, serta paket data yang dikeluarkan menjadi cukup banyak selama pembelajaran elearning" (4/W/ANA/16-03-2021)

Hal serupa juga disampaikan oleh narasumber SM selaku guru ekonomi kelas X SMA Labschool Unesa:

"Yang pertama terkendala jaringan, jaringan itu kendalanya tidak hanya di peserta didik namun juga di gurunya. Semisal hari ini wifi kami sedang ada masalah jadi berpengaruh terhadap pembelajaran. Jadi kendala yang paling utama adalah jaringan, untuk kendala yang lainnya masih bisa diatasi" (1/W/SMS/26-02-2021)

Selain itu berdasarkan hasil kuisioner pada tabel berikut menunjukkan bahwa dengan diterapkannya pembelajaran e-learning peserta didik menjadi kurang dekat dengan peserta didik lainnya maupun dengan guru

Tabel 7. Saya menjadi kurang dekat dengan guru dan teman karena menggunakan pembelajaran e-learning

\begin{tabular}{ccc}
\hline $\begin{array}{c}\text { Alternatif } \\
\text { Jawaban }\end{array}$ & $\begin{array}{c}\text { Frekuensi } \\
\text { Informan }\end{array}$ & $\mathbf{\%}$ \\
\hline Ya & 19 & 67,9 \\
\hline Tidak & 9 & 32,1 \\
\hline Total & 28 & 100 \\
\hline
\end{tabular}

2. Minat belajar peserta didik SMA Labschool pada mata pelajaran Ekonomi di masa pandemi COVID-19

Minat belajar peserta didik dapat ditinjau dari beberapa indikator. Indikator tersebut meliputi perasaan senang, ketertarikan dalam belajar, perhatian dalam belajar, dan keterlibatan dalam 
belajar. Hasil paparan data yang didapat pada tiap indikator adalah sebagai berikut:

\section{a) Perasaan Senang}

Indikator perasaan senang dilihat berdasarkan dari peserta didik merasa senang sehingga tertarik dalam mengikuti pelajaran tanpa adanya rasa bosan saat menggikuti proses pembelajaran, Kuisioner pada tabel berikut menunjukkan bahwa 22 dari 28 peserta didik mengalami bosan mengikuti pembelajaran.

Tabel 8. Saya sering merasa bosan mengikuti pembelajaran berbasis e-learning

\begin{tabular}{ccc}
\hline $\begin{array}{c}\text { Alternatif } \\
\text { Jawaban }\end{array}$ & $\begin{array}{c}\text { Frekuensi } \\
\text { Informan }\end{array}$ & \% \\
\hline Ya & 22 & 78,6 \\
\hline Tidak & 6 & 21,4 \\
\hline Total & 28 & 100 \\
\hline
\end{tabular}

Pernyataan tersebut didukung dengan wawancara oleh narasumber yang menjelaskan bahwa:

"Bosen pasti ada sih pak, tapi ya mau bagaimana lagi masih pandemi. Jadi mau gak mau harus tetap semangat buat memahami materi"(3/W/MRS/15-03-2021)

" Kebanyakan bosen karena hanya mendengarkan dan melihat gadget pak"(2/W/LA/15-03-2021)

"Lebih ngebosenin sih pak, karena gak ada temen yang diajak dikusi. Kalau udah bosen harus cepat-cepat cari cara biar gak bosen"(5/W/AKBG/15-03-2021)

Berdasarkan wawancara tersebut menunjukkan bahwa sebagian besar perasaan senang peserta didik kurang, hal tersebut didukung dengan mereka yang merasa bosan dengan proses pembelajaran yang diterapkan.

\section{b) Ketertarikan dalam belajar}

Pada indikator ketertarikan dalam belajar dapat ditinjau dari menunjukan rasa ketertarikan kepada guru dan kegiatan pembelajaran, Berdasarkan hasil kuisioner pada tabel berikut menunjukkan bahwa:

Tabel 9. Saya lebih senang mengikuti pembelajaran e-learning daripada pembelajaran secara langsung

\begin{tabular}{ccc}
\hline $\begin{array}{c}\text { Alternatif } \\
\text { Jawaban }\end{array}$ & $\begin{array}{c}\text { Frekuensi } \\
\text { Informan }\end{array}$ & \% \\
\hline Ya & 4 & 14,3 \\
\hline Tidak & 24 & 85,7 \\
\hline Total & 28 & 100 \\
\hline
\end{tabular}

Dari tabel diatas dapat disimpulkan bahwa sebagian peserta didik lebih senang dan tertarik terhadap proses pembelajaran secara langsung. Hal ini dapat dilihat dari hasil kuisioner yang menunjukkan bahwa 24 dari 28 peserta didik tidak merasa senang dengan diterapkannya pembelajaran e-learning.

Hal serupa juga disampaikan Ibu SM selaku guru ekonomi kels X SMA Labschool, yang menyatakan bahwa:

"Kebanyakan peserta didik tidak suka dengan pembelajaran seperti ini, alasan yang menjadikan mereka tidak suka adalah yang pertama adalah mereka bosen belajar sendiri dirumah yang kedua mereka tidak bisa ketemu dengan temannya dan yang ketiga biasanya masalah alat yang tersedia di rumah antarala lain sinyal maupun laptop serta handphone. Seperti ini menjadikan peserta didik yang semula pintar aktif rajin menjadi menurun tingkat ketertarikannya dalam belajar.(1/W/SMS/26-02-2021)

\section{c) Perhatian dalam belajar}

Dapat ditinjau dari fokus saat mengikuti pembelajaran Ekonomi, Dari hasil wawancara yang didapat dengan Ibu SM yang menyatakan bahwa:

"Kalau pembelajaran seperti ini guru dituntut untuk lebih jeli lagi dalam penilaian, karena tidak bisa kita semena-mena jika peserta didik diam tidak menjawab itu mereka tidak memerhatikan. Malahan mereka yang seperti itu di dalam pengerjaan tugas maupun ulangan itu nilainya bagus, jadi belum tentu mereka tidak memerhatikan kita yang sedang mengajar. Namun kebanyak dari mereka tetp focus memerhatikan walaupun ada satu dua anak yang bosan itu wajar" (1/W/SMS/26-02-2021)

Dari hasil kuisioner pada tabel berikut juga menunjukkan bahwa 23 dari 28 peserta mengikuti pembelajaran dengan sungguhsungguh

Tabel 10. Selama pembelajaran e-learning saya bersungguh-sungguh memperhatikan penjelasan materi yang disampaikan oleh guru

\begin{tabular}{ccc}
\hline $\begin{array}{c}\text { Alternatif } \\
\text { Jawaban }\end{array}$ & $\begin{array}{c}\text { Frekuensi } \\
\text { Informan }\end{array}$ & \% \\
\hline Ya & 23 & 82,1 \\
\hline Tidak & 5 & 17,9 \\
\hline Total & 28 & 100 \\
\hline
\end{tabular}

\section{d) Keterlibatan dalam belajar}

Indikator keterlibatan dalam belajar dapat dilihat dari peserta didik aktif dalam pembelajaran tersebut serta berusaha menjawab setiap pertanyaan-pertanyaan yang diaajukan oleh guru. 
Tabel 11. Saya selalu berusaha menjawab pertanyaan yang diberikan oleh guru dengan baik selama pembelajaran e-learning

\begin{tabular}{ccc}
\hline $\begin{array}{c}\text { Alternatif } \\
\text { Jawaban }\end{array}$ & $\begin{array}{c}\text { Frekuensi } \\
\text { Informan }\end{array}$ & \% \\
\hline Ya & 23 & 82,1 \\
\hline Tidak & 5 & 17,9 \\
\hline Total & 28 & 100 \\
\hline
\end{tabular}

Dari tabel diatas menunjukkan bahwa 23 dari 28 peserta didik berusaha menjawab setiap pertanyaan yang diberikan oleh guru dengan baik. Hal ini menjelaskan bahwa keterlibatan peserta didik dalam belajar sudah cukup baik, Hal serupa juga di ungkapkan oleh Ibu SM yang menyatakan bahwa:

"Ya ada beberapa anak yang malas, itu wajar saja. Tetapi untuk keseluruhan mereka mengerjakan tugas dengan baik, jika di beri pertanyaan juga aktif. Namun itu semua juga tergantung guru dalam mengajar, harus pintarpintar kita guru mengolah pembelajaran seperti apa" (1/W/SMS/26-02-2021)

e) Minat belajar peserta didik pada mata pelajaran Ekonomi dengan diterapkannya pembelajaran e-learning di masa pandemi COVID-19

Berdasarkan wawancara yang dilakukan oleh bebrapa narasumber menyatakan bahwa:

"Sangat berpengaruh kak, karna jika ada materi yang tidak dipahami pasti lebih cenderung malas mencari materi tersebut karena tidak adanya bantuan guru, lalu bosan waktu zoom/gmeet"(2/W/LA/15-03-2021).

"Sedikit minat saya untuk belajar, kecuali kalau ada ulangan sama ada tugas kak" (3/W/MRS/15-03-2021).

"Berpengaruh kak, jika materi yang disampaikan kurang jelas jadi bikin males belajar" (4/W/ANA/16-03-2021).

Hal yang sama juga disampaikan Ibu SM yang menyatakan bahwa:

"Sangat berpengaruh mas, minat peserta didik menjadi turun dengan adanya penerapan pembelajaran seperti ini, yang kemungkinan karena mereka sudah bosen terlalu lama belajar sendiri di rumah" (1/W/SMS/26-022021)

\section{B. Pembahasan}

Proses pembelajaran e-learning di SMA Labschool pada masa pendemi COVID-19

Dari hasil paparan data yang telah diperoleh, indikator pembelajaran e-learning dapat ditinjau dari beberapa indikator, antara lain: a. Pengetahuan tentang e-learning

Indikator pertama dapat ditinjau dari penerapan pembelajaran e-learning. Dari hasil penelitian yang diperoleh dilapangan dengan melakukan wawancara dan kuisioner menjelaskan bahwa penerapan pembelajaran yang dilakukan di SMA Labschool Unesa sudah termasuk dalam kategori sangat baik. Hal ini juga sejalan dengan pihak sekolah yang bekerja sama dengan penyedia jasa media pembelajaran online yang menjadikan peserta didik mampu menerapkan pembelajaran $e$ learning dengan baik tanpa mengalami kendala yang berarti

b. Karakteristik pembelajaran e-learning

Indikator yang kedua yakni, karakteristik pembelajaran e-learning ditinjau berdasarkan interaktivitas, kemandirian, serta aksesibilitas. Hasil menunjukkan bahwa dengan adanya penerapan pembelajaran e-learning menjadikan peserta didik mampu belajar secara mandiri di rumah selain itu juga memudahkan mereka mengakses pembelajaran dengan baik. Hal ini dapat disimpulkan bahwa karakteristik pembelajaran e-learning sudah diterapkan dengan cukup baik.

c. Manfaat pembelajaran e-learning

Pada indikator manfaat e-learning dapat ditinjau dari kemudahan berkomunikasi, kemudahan me-review pelajaran, dan kemudahan belajar. Dari paparan data yang telah diperoleh sebagian peserta didik memperoleh manfaat yang cukup banyak dengan diterapkannya pembelajaran e-learning, pembelajaran e-learning memudahkan mereka untuk tetap belajar walaupun di masa pandemi sekarang ini, serta juga menjadikan mereka lebih tanggap teknologi. Selain manfaat yang dirasakan peserta didik, pihak sekolah maupun guru juga merasakan manfaat dari pembelajaran e-learning.

\section{d. Kendala pembelajaran e-learning}

Indikator yang terakhir yakni kendala pembelajaran e-learning dapat ditinjau dari jaringan Internet, dan interaksi berkurang. Hasil paparan data diperoleh bahwa hal yang paling utama kendala yang sebagian peserta didik alami yaitu berhubungan dengan jaringan internet. Hal ini tidak hanya dirasakan oleh peserta didik saja, guru pun juga sering mengalami kendala dengan jaringan internet. Selain itu dengan diterapkannya pembelajaran e-learning menjadikan peserta didik kurang dekat dengan sesama peserta didik maupun dengan guru mereka.

Berdasarkan hasil pada tiap indikator menunjukkan bahwa pembelajaran e-learning 
yang diterapkan di SMA Labschool Unesa pada masa pandemi COVID-19 sudah berjalan cukup baik, namun perluh adanya solusi yang di ambil untuk mengatasi kendala dari pembelajaran $e$ learning tersebut. Dari kendala yang telah diteliti menunjukkan bahwa kendala yang cukup besar dirasakan adalah dari segi jaringan internet.

\section{Minat belajar peserta didik SMA Labschool pada mata pelajaran Ekonomi di masa pandemi COVID-19}

Minat belajar peserta didik dapat dilihat dari beberapa indikator, antara lainnya adalah:

a. Perasaan senang

Indikator perasaan senang dapat dilihat dari perasaan senang peserta didik sehingga tertarik dalam mengikuti kegiatan pembelajaran serta tanpa adanya rasa bosan saat mengikuti pembelajaran. Hasil dari penelitian yang telah dilaksanakan menunjukkan hasil bahwa sebagian besar peserta didik mengalami perasaan bosan dalam mengikuti pembelajaran e-learning. Mereka tidak senang dengan di terapkannya pembelajaran e-learning, karena peserta didik merasa pembelajaran seperti ini menyulitkan mereka dalam memahami materi yang dijelaskan oleh guru.

b. Ketertariakan dalam belajar

Ketertarikan dalam belajar dapat ditinjau dari menunjukan rasa ketertarikan kepada guru dan kegiatan pembelajaran. Dari paparan data yang diperoleh dijelaskan bahwa sebagian peserta didik kurang tertarik dengan pembelajaran yang dilakukan secara e-learning. Dari pernyataan yang mereka jelaskan bahwa mereka tidak suka dengen pembelajaran $e$ learning, mereka lebih suka jika pembelajaran di laksanakan secara langsung di sekolah. Hal ini sejalan dengan pernyataan guru ekonomi yang menjelaskan bahwa peserta didik lebih tertarik maupaun menyukai pembelajaran langsung di kelas.

c. Perhatian dalam belajar

Pada indikator perhatian dalam belajar ini dapat dilihat dari peserta didik aktif dalam pembelajaran tersebut serta berusaha menjawab setiap pertanyaan-pertanyaan yang diaajukan oleh guru. Menurut hasil penelitian yang telah dilakukan diperoleh hasil bahwa perhatian peserta didik cukup baik. Mereka cukup aktif dalam mengikuti pembelajaran walaupun ada beberapa peserta didik yang pasif namun hal itu tidak mengurangi perhatian peserta didik lain dalam mengikuti pelajaran.

d. Keterlibatan dalam belajar

Indikator ke empat yakni keterlibatan dalam belajar dapat ditinjau berdasarkan peserta didik aktif dalam pembelajaran tersebut serta berusaha menjawab setiap pertanyaan-pertanyaan yang diaajukan oleh guru. Dari hasil penelitian menjelaskan bahwa walaupun mereka merasa bosan namun peserta didik tetap berusaha menjawab setiap pertanyaan yang diajukan oleh guru. Mereka berusaha tetap semangat mengikuti pemelajaran dengan baik.

Berdasarkan hasil dari beberapa indikator menjelaskan bahwa minat belajar peserta didik SMA Labschool pada mata pelajaran Ekonomi di masa pandemi COVID-19 masih cukup kurang, perluh adamya cara yang diterapkan untuk meningkatkan minat belajar peserta didik di masa pandemi sekarang ini. Mereka merasa bosan dengan terlalu lamanya penerapan pembelajaran e-learning.

\section{Minat belajar peserta didik pada mata pelajaran Ekonomi dengan diterapkannya pembelajaran e-learning di masa pandemi COVID-19}

Dari hasil wawancara yang dilakukan terhadap peserta didik diperoleh hasil bahwa pembelajaran e-learning ini sangat berpengaruh terhadap minat belajar mereka, mereka mengeluh malas belajar dikarenakan mereka merasa bosen belajar sendiri di rumah, apalagi jika materi yang mereka pelajari kurang dimengerti. Mereka hanya akan belajar jika ada tugas maupun ujian. Pernyataan ini juga dibenarkan oleh guru Ekonomi SMA Labschool Unesa yang menjelaskan bahwa dengan penerapan pembelajaran e-learning minat belajar peserta didik mengalami penurunan. Dari hasil wawancara telah yang dilakukan oleh pihak sekolah kepada peserta didik menjelaskan bahwa, banyak peserta didik yang mengeluhkan jika mereka bosan dengan penerapan pembelajaran seperti ini, hal ini yang menjadikan minat belajar peserta didik mengalami penurunan.

\section{SIMPULAN DAN SARAN}

A. Simpulan

Berdasar pada hasil penelitian dan pembahasan yang telah dilakukan maka kesimpulan yang diperoleh antara lain:

a) Pembelajaran e-learning dapat ditinjau dari beberapa indikator. Berdasarkan secara keseluruhan tiap indikator pembelajaran $e$ learning yang telah dilakukan di SMA Labschool Unesa pada masa pandemi terbilang cukup baik, namun masih perluh adanya perbaikan sehingga pembelajaran dapat dijalankan secara maksimal.

b) Minat belajar peserta didik SMA Labschool Unesa pada masa pandemi COVID-19 terbilang cukup kurang. Hal ini dapat dilihat dari beberapa indikator yang menunjukkan bahwa rendahnya minat belajar Ekonomi 
peserta didik dalam pembelajaran $E$ Learning.

c) Pembelajaran e-learning sangat membawa pengaruh bagi peserta didik SMA Labschool Unesa. Dengan diterapkannya pembelajaran e-learning minat belajar Ekonomi peserta didik mengalami penurunan jika dibandingkan dengan pembelajaran secara langsung.

\section{B. Saran}

Bagi Guru Ekonomi disarankan untuk mencari solusi bagi kendala yang dihadapi selama penerapan pembelajaran e-learning, sehingga penerapan pembelajaran bisa berjalan dengan baik. Serta lebih meningkatkan kreatifitas dalam proses pembelajaran sehingga minat belajar peserta didik dalam pembelajaran e-learning tidak menurun, Bagi sekolah disarankan agar meningkatkan infrastruktur untuk menunjang pembelajaran e-learning agar dapat berjalan secara maksimal, selain itu juga mendukung guru dalam meningkatkan kreatifitas dalam pengelolaan pembelajaran, dan Bagi Peserta didik, disarankan untuk lebih meningkatkan minat belajar pada masa pandemi seperti ini, dengan merubah cara belajar atau suasana belajar yang membuat peserta didik merasa nyaman dalam belajar.

\section{DAFTAR RUJUKAN}

Adriani, R. (2020). EVALUASI PEMBELAJARAN ONLINE MATEMATIKA SISWA KELAS 5 SD NEGERI 5 METRO PUSAT Oleh: RITA ANDRI ANI Jurusan: Pendidikan Guru Madrasah Ibtidaiyah ( PGMI) Fakultas: Tarbiyah dan Ilmu Keguruan INSTITUT AGAMA ISLAM NEGERI ( IAIN) METRO LAMPUNG. 135.

Ahmadi, R. (2014). Penelitian - Metode Kualitatif. ArRuzz Media.

Anam, K. (2015). Pengaruh Media Pembelajaran Terhadap Minat Belajar Siswa pada Mata Pelajaran PAI di SMP Bani Muqiman Bangkalan. Tadarus: Jurnal Pendidikan Islam, 4(2), 1-17.

Anggito, A., \& Setiawan, J. (2018). METODOLOGI PENELITIAN KUALITATIF (E. D. Lestari (ed.)). CV.Jejak.

Helaluddin, \& Wijaya, H. (2019). Qualitative Data Analysis A Review of Theory and Practice.

Herdiansyah, H. (2010). Metode Penelitian Kualitatif untuk Ilmu-ilmu Sosial. Salemba Humanika.

Ilyas Yasin. (2021). Konstruksi Pluralisme Agama dalam Praktik Pembelajaran Pendidikan Agama Islam di SMA Negeri 1 Dompu. Ainara Journal (Jurnal Penelitian Dan PKM Bidang Ilmu Pendidikan), 2(1), 30-37.

https://doi.org/10.1234567/ainarajournal.v2i1.22
Jamaluddin, D., Ratnasih, T., Gunawan, H., \& Paujiah, E. (2020). Pembelajaran Daring Masa Pandemik Covid-19 Pada Calon Guru: Hambatan, Solusi Dan Proyeksi. Karya Tulis Ilmiah UIN Sunan Gunung Djjati Bandung, 1-10. http://digilib.uinsgd.ac.id/30518/

Kahar, I. (2018). PENGARUH MOTIVASI DAN MINAT BELAJAR SISWA KELAS X TERHADAP HASIL BELAJAR SERVIS ATAS BOLA VOLI SMANEGERI 18 LUWU. Skripsi, 489(20), 313-335.

Maya Rahmatia, Monawati, S. D. (2017). PENGARUH MEDIA E-LEARNING TERHADAP HASIL BELAJAR MATEMATIKA SISWA KELAS IV SDN 20 BANDA ACEH Maya Rahmatia, Monawati, Said Darnius. Jurnal Ilmiah Pendidikan Guru Sekolah Dasar FKIP Unsyiah Volume 2 Nomor 1, 212-227 Februari 2017, 2, 212-227.

Ninu Septiani. (2016). Pengaruh Minat Dan Motivasi Belajar Terhadap Hasil Belajar Siswa Kelas V SDN GUGUS WERKUDORO KEC TEGAL TIMUR KOTA TEGAL.

Nuri, N. (2017). KABA MINANGKABAU: EKSISTENSI PEREMPUAN DALAM KONTEKS SISTEM SOSIAL $B U D A Y A$ (A. Gunawan (ed.)). ISI Padangpanjang.

Partyaningsih. (2020). ANALISIS PENGGUNAAN MEDIA DARING ERA COVID-19 TERHADAP MOTIVASI BELAJAR PAI DAN BUDI PEKERTI PADA SISWA KELAS X SMK NEGERI 1 SALATIGA TAHUN AJARAN 2019/2020. Skripsi, 9, 145.

Pratiwi, N. K. (2015). Pengaruh Tingkat Pendidikan, Perhatian Orang Tua, dan Minat Belajar Siswa terhadap Prestasi Belajar Bahasa Indonesia Siswa SMK Kesehatan di Kota Tangerang. Jurnal Pujangga, 1(2), 75-105.

Ramadani, J. (2019). ANALISIS INDIKATOR INSTRUMEN KECEMASAN, MINAT DAN MOTIVASI BELAJAR MATEMATIKA SISWA SEKOLAH MENENGAH PERTAMA MENGGUNAKAN CONFIRMATORY FACTOR ANALYSIS (Study Kasus: SMP Negeri 12 Bandar Lampung). Skripsi.

Ridwan, M. (2011). Pengaruh Pembelajaran Berbasis E-learning Terhadap Prestasi Belajar Siswa Kelas XII Akuntansi Mata Pelajaran Fiqih di SMK YPM 3 Taman Sidoarjo. Skripsi, 1999, 13-76.

Sarahutu, M. G. (2020). PEMBELAJARAN ONLINE, MINAT BELAJAR, DAN KEHIDUPAN SEHARIHARI MAHASISWA PENDIDIKAN FISIKA UNIVERSITAS SANATA DHARMA DI TENGAH COVID-19. Pembelajaran Online, Minat Belajar, Dan Kehidupan Sehari-Hari Mahasiswa Pendidikan Fisika Universitas Sanata Dharma Di Tengah Covid-19 Skripsi, 1 of 140. 
Setiawardhani, R. T. (2013). Pembelajaran Elektornik (E-learning) dan Internet dalam Rangka Mengoptimalkan Kreativitas Belajar Siswa. Jurnal Ilmiah Pendidikan Ekonomi Unswagati, 1(2), 8296.

Shofiyah, S. (2016). Pengaruh Penggunaan Android dan E-Learning terhadap Hasil Belajar Mata Pelajaran IPS Siswa Kelas VIII SMPN 3 Kepanjen Malang. Skripsi.

Sholihah, A. (2016). Analisis Pengaruh Motivasi Belajar dan Lingkungan Belajar terhadap Hasil Belajar. 1-5.

Siagian, R. E. F. (2015). Pengaruh Minat dan Kebiasaan Belajar Siswa terhadap Prestasi Belajar Matematika. Formatif: Jurnal Ilmiah Pendidikan MIPA, 2(2), 122-131. https://doi.org/10.30998/formatif.v2i2.93

Simanihuruk, L., Simarmata, J., Sudirman, A., Hasibuan, M. S., Safitri, M., Sulaiman, O. K., Ramadhani, R., \& Sahir, S. H. (2019). E-learning: Implementasi, Strategi dan Inovasinya (T. Limbong (ed.)). Yayasan KIta Menulis.

Sirait, E. D. (2016). Pengaruh Minat Belajar terhadap Prestasi Belajar Matematika. Jurnal Formatif, 6(1), 35-43.
Slameto. (2003). Belajar dan Faktor-faktor yang Mempengaruhinya. PT. Raja Grafindo Persada.

Sugiarto, E. (2015). Menyusun Proposal Peneitian Kualitatif: Skripsi dan Tesis: Suaka Media. Suaka Media.

Susilo, A., Rumende, C. M., Pitoyo, C. W., Santoso, W. D., Yulianti, M., Herikurniawan, H., Sinto, R., Singh, G., Nainggolan, L., Nelwan, E. J., Chen, L. K., Widhani, A., Wijaya, E., Wicaksana, B., Maksum, M., Annisa, F., Jasirwan, C. O. M., \& Yunihastuti, E. (2020). Coronavirus Disease 2019: Tinjauan Literatur Terkini. Jurnal Penyakit Dalam Indonesia, $\quad 7(1), \quad 45$. https://doi.org/10.7454/jpdi.v7i1.415

Wijaya, H. (2018). Analisis Data Kualitatif Ilmu Pendidikan Teologi. Sekolah Tinggi Theologia Jaffry.

Wina, S. (2013). Penelitian Pendidikan: Jenis, Metode dan Prosedur (1st ed.). Kencana Prenada Media Group. 